\title{
Methylation of CPG sites in the upstream regulatory region, physical status and mRNA expression of HPV-6 in adult-onset laryngeal papilloma
}

\author{
Zeyi Deng ${ }^{1,2}$, Taro Ikegami ${ }^{2}$, Asanori Kiyuna ${ }^{2}$, Chunlin Zhang ${ }^{1,2,3}$, Tao Zhang ${ }^{1}$, Sen \\ Matayoshi², Takayuki Uehara², Hiroyuki Maeda², Mikio Suzuki² and Akira Ganaha ${ }^{2}$ \\ ${ }^{1}$ Department of Otorhinolaryngology, Head and Neck Surgery, Zhujiang Hospital, Southern Medical University, Guangzhou, \\ China \\ ${ }^{2}$ Department of Otorhinolaryngology, Head and Neck Surgery, Graduate School of Medicine, University of the Ryukyus, \\ Okinawa, Japan \\ ${ }^{3}$ Department of Otorhinolaryngology, Head and Neck Surgery, Affiliated Hospital of Zunyi Medical College, Zunyi, China \\ Correspondence to: Zeyi Deng, email: jordandzy@hotmail.com
}

Keywords: adult-onset laryngeal papilloma, human papillomavirus-6, methylation, physical status, mRNA expression

Received: November 05, $2016 \quad$ Accepted: July 13,2017 Published: August 03, 2017

Copyright: Deng et al. This is an open-access article distributed under the terms of the Creative Commons Attribution License 3.0 (CC BY 3.0), which permits unrestricted use, distribution, and reproduction in any medium, provided the original author and source are credited.

\section{ABSTRACT}

The methylation status of HPV-6 upstream regulatory region (URR) in adult-onset laryngeal papillomatosis (AO-LP) remains unclear. The purpose of this study was to investigate the methylation status of URR and the physical status of HPV-6, as well as the dynamic variations of viral load and mRNA expression in AO-LP. We examined 18 specimens from 11 patients with AO-LP by real-time polymerase chain reaction (PCR), bisulfite-sequencing PCR, and amplification of papilloma oncogene transcripts. HPV-6 was identified in 9 of 11 patients $(81.8 \%)$, and all the 15 specimens derived from 9 HPV-6-positive cases contained only episomal HPV-6 transcripts with intact E2. Three HPV-6-positive patients developed recurrent lesions, and HPV-6 copy numbers and mRNA expression decreased after surgical treatment. Among the 96 CpG sites (16/case), $67(69.8 \%)$ were unmethylated, while $23(30.2 \%)$ were heterogeneous ( $\geq 1$ methylated CpG clone). High viral loads and episomal status of HPV-6 were frequently observed in AO-LP; thus, persistent E6/E7 mRNA expression of LR-HPV-6 may be associated with AO-LP recurrences. Hypomethylation and scattered patterns of methylated CpGs at the URR of HPV-6 were identified in AO-LP.

\section{INTRODUCTION}

Human papillomaviruses (HPVs) are small icosahedral viruses containing 8 or 9 genes on circular double-stranded DNA. More than 150 types have been identified to date. HPV infection can stimulate benign tumors, promote oncogenic changes, or be asymptomatic in epithelial cells [1]. Adult-onset laryngeal papillomatosis (AO-LP), usually a benign tumor of the larynx, is induced by low-risk human papillomaviruses (LR-HPVs), especially HPV-6 and -11 $[2,3]$. AO-LP is characterized by recurrences and warty exophytic lesions in the larynx, but can spread to the whole respiratory tract including the lungs in up to $20 \%$ of adult patients [2, 4]. The recurrent nature of AO-LP could be due to persistent viral reservoirs and activation of asymptomatic HPV infections [5]. Malignant transformation can occur, but this has been reported in less than $3 \%$ of cases $[6,7]$.

It is well known that oncogenic HPVs encode two main viral oncoproteins, E6 and E7, which are responsible for the maintenance of HPV-mediated malignant transformation by their interactions with $\mathrm{p} 53$ and retinoblastoma $(\mathrm{pRb})$ tumor suppressor proteins, respectively. Unlike high-risk HPVs, E6 and E7 proteins of LR-HPVs have substantially lower transforming activity and do not induce genomic instability. LR-HPV E6 proteins lack the ability to degrade and inactivate p53 [8], while low-risk E7 proteins bind to pRb less 
efficiently and do not induce pRb destabilization [9]. The viral E2 protein participates in viral DNA replication and transcription and regulates the expression of E6 and E7 oncogenes. Moreover, the activities of E2 protein are related to its ability to bind to 4 conserved E2 binding sites (E2BS) in the upstream regulatory region (URR), especially the early promoter $\mathrm{p} 97[10,11]$.

The methylation status of the HPV-16 genome in cancer cell lines and clinical samples of the cervix, head, and neck has been analyzed and identified as an important feature in malignant transformation [12-16]. Previous studies have reported progressive methylation of URR in HPV-16-infected cervical specimens, and HPV-16 URR methylation rates of $5.9 \%, 33.3 \%$, and $53.3 \%$ in lowgrade squamous intraepithelial lesion (SIL), high-grade SIL, and squamous cell carcinoma (SCC), respectively. Moreover, de novo methylation or mutations of E2BSs in the URR might cause upregulation of $E 6$ and $E 7$ oncogene expression by impairing the ability of $E 2$ to bind to its specific sites $[12,17]$. In a study by Park et al., 9 of 22 (41\%) oropharyngeal SCCs were methylated in more than $50 \%$ of the $\mathrm{CpG}$ sites at either the $E 6$ enhancer region or the E2BS [14]. However, few reports have been published to date and knowledge on the methylation of LR-HPVs in AO-LP is limited. Ure and Forslund [18] demonstrated that the URR of HPV-6 is completely unmethylated in papillomas of the aerodigestive tract, which is very different from findings in malignant tissues of the cervix and oropharynx. Nevertheless, the methylation status of the HPV-6 URR in AO-LP was not established because of the relatively limited number of specimens in the previous study. In addition, a high HPV-16 load was found to correlate significantly with E6/E7 mRNA expression in SCC of the head and neck in our previous study, suggesting that variations in HPV viral load might reflect differences in the capacity of the viral DNA to replicate and its transcriptional activity [19]. With respect to LRHPV tumorigenesis in AO-LP, the relationship between the dynamic variations among LR-HPV loads and the high rate of AO-LP recurrences remain to be clarified.

In this study, we investigated the methylation status of the URR of LR-HPV-6, the physical status and expression of E6/E7 mRNA in AO-LP, and the dynamic variations of HPV-6 among primary tumors and recurrent tumors after treatment. Moreover, we analyzed the relationship between the methylation pattern of the HPV6 URR and viral load in AO-LP.

\section{RESULTS}

\section{Prevalence of HPV and subtypes in AO-LP}

The clinicopathological characteristics of 18 specimens obtained from 11 patients with laryngeal papilloma are summarized in Table 1. All patients underwent surgical treatment, including three cases who underwent at least 2 operations. The mean interval to recurrence was 13.0 months among the 3 cases (case 5 , case 6 , and case 7 ). In case 5 , the primary lesion was unilateral but the tumor in the second recurrence developed bilaterally in the true vocal cords. The prevalence of HPV in AO-LP was $81.8 \%$ (9 of 11), and all HPV-positive samples were infected with the LR-HPV-6 subtype. Only 1 of the 11 patients (case 8) developed laryngeal SCC within 2 years of receiving surgery for laryngeal papilloma; however, HPV DNA was not found in either the malignant or benign lesions in this case.

\section{HPV-6 viral load, E6 mRNA expression, and dynamic variation pre- and post-operation}

The pre-operative viral load in 9 primary laryngeal papilloma samples positive for HPV-6 DNA was first evaluated. The relative HPV-6 viral load was normalized by the $\beta$-globin standard curve and adjusted to values per nanogram of input DNA for each sample. The viral load of HPV-6 ranged from 2,933 to 2,268,452 copies/ng, with a median of 391,015 copies/ng. E6 mRNA transcripts for HPV-6 were detected in all cases positive for HPV-6 DNA, and the median mRNA quantity was 0.20 (range 0.08 to 0.43 ).

During the observation period, 3 of the 9 HPV-6positive patients developed recurrent lesions. Viral loads of 712,653 copies/ng in primary lesions in case 7 decreased to 267,558 copies/ng in recurrent lesions (Figure 1A). The expression levels of $E 6 \mathrm{mRNA}$ in case 7 slightly decreased from 0.21 to 0.15 . Case 5 had 4 recurrences after the primary operation, and the viral load and the expression of E6 mRNA gradually decreased from 178,463 and 0.18, respectively, to 9,550 and 0.10 . (Figure 1B).

\section{Physical status analysis of HPV-6 by amplification of papillomavirus oncogene transcripts assay}

A 3'-RACE polymerase chain reaction (PCR) that allows differentiation between episome- and integratederived E6/E7 mRNA transcripts was used to determine the physical statuses of the HPV-6 genomes [20]. Regardless of whether the lesions were initial or recurrent lesions, all 15 specimens derived from the 9 HPV-positive patients contained only episomal HPV-6 transcripts with intact $E 2$. No integrated-derived E6/E7 mRNA transcripts were found in these samples (Figure 2).

\section{Methylation pattern of $\mathrm{CpGs}$ at the upstream regulatory region of $\mathrm{HPV}-6$ in $\mathrm{AO}-\mathrm{LP}$}

Based on a manual comparison of sequence data from the URR as described by Combrinck et al. [21], HPV-6a, HPV-6b, and HPV-6vc were identified in 2 patients, 2 patients, and 4 patients, respectively (Table 1). 
Table 1: Clinicopathological characteristics of 11 patients with AO-LP

\begin{tabular}{|c|c|c|c|c|c|c|c|c|c|c|c|c|}
\hline $\begin{array}{l}\text { Case } \\
\text { No. }\end{array}$ & $\begin{array}{c}\text { Age } \\
\text { (years) }\end{array}$ & Sex & $\begin{array}{l}\text { Tumor } \\
\text { size }\end{array}$ & Subsite & HPV & $\begin{array}{c}\text { Viral load } \\
\text { (copies/ } \\
\text { ng DNA) }\end{array}$ & $\begin{array}{c}\text { mRNA } \\
\text { (E6/actin) }\end{array}$ & APOT & p16 & p53 & pRb & MT \\
\hline 1 & 31 & M & $12 \mathrm{~mm}$ & $\mathrm{R}, \mathrm{TVC}$ & HPV-6b & 603,566 & 0.18 & Epi. & + & - & - & $\mathrm{N}$ \\
\hline 2 & 58 & $\mathrm{~F}$ & $20 \mathrm{~mm}$ & $\mathrm{R}, \mathrm{AF}$ & - & & & & - & + & + & $\mathrm{N}$ \\
\hline 3 & 27 & M & $14 \mathrm{~mm}$ & R, FVC & HPV-6a & $2,268,452$ & 0.08 & Epi. & + & - & - & $\mathrm{N}$ \\
\hline 4 & 43 & M & $7 \mathrm{~mm}$ & $\mathrm{~B}, \mathrm{TVC}$ & HPV-6b & 676,099 & 0.26 & Epi. & - & - & + & $\mathrm{N}$ \\
\hline 5 & 67 & M & $12 \mathrm{~mm}$ & L, TVC & HPV-6vc & 178,463 & 0.18 & Epi. & - & - & + & $\mathrm{N}$ \\
\hline 5-R1 & & & $10 \mathrm{~mm}$ & L, TVC & & 132,452 & 0.31 & & & & & \\
\hline $5-R 2$ & & & $15 \mathrm{~mm}$ & $\mathrm{~B}, \mathrm{TVC}$ & & 182,549 & 0.32 & & & & & \\
\hline 5-R3 & & & $12 \mathrm{~mm}$ & $\mathrm{~B}, \mathrm{TVC}$ & & 28,594 & & & & & & \\
\hline $5-\mathrm{R} 4$ & & & $12 \mathrm{~mm}$ & $\mathrm{~B}, \mathrm{TVC}$ & & 9,550 & 0.10 & & & & & \\
\hline 6 & 17 & $\mathrm{~F}$ & $10 \mathrm{~mm}$ & B, TVC & HPV-6vc & 31,725 & 0.08 & Epi. & - & - & - & $\mathrm{N}$ \\
\hline 6-R1 & & & $12 \mathrm{~mm}$ & $\mathrm{R}, \mathrm{TVC}$ & & 27,756 & 0.06 & & & & & \\
\hline 7 & 59 & M & $8 \mathrm{~mm}$ & B, TVC & HPV-6ve & 712,653 & 0.21 & Epi. & - & - & - & $\mathrm{N}$ \\
\hline 7-R1 & & & $8 \mathrm{~mm}$ & B, TVC & & 266,558 & 0.15 & & & & & \\
\hline 8 & 66 & M & $20 \mathrm{~mm}$ & $\mathrm{R}, \mathrm{TVC}$ & - & & & & - & - & - & $\mathrm{Y}$ \\
\hline 8-R1 & & & $18 \mathrm{~mm}$ & $\mathrm{R}, \mathrm{TVC}$ & & & & & & & & \\
\hline 9 & 45 & M & $10 \mathrm{~mm}$ & $\mathrm{~B}, \mathrm{TVC}$ & HPV-6* & ND & ND & Epi. & - & + & + & $\mathrm{N}$ \\
\hline 10 & 41 & M & $6 \mathrm{~mm}$ & $\mathrm{R}, \mathrm{TVC}$ & HPV-6ve & 25,346 & 0.42 & Epi. & & & & $\mathrm{N}$ \\
\hline 11 & 32 & M & $18 \mathrm{~mm}$ & $\begin{array}{l}\text { B, TVC } \\
\text { B, FVC }\end{array}$ & HPV-6a & 2,933 & 0.43 & Epi. & & & & $\mathrm{N}$ \\
\hline
\end{tabular}

AO-LP, adult-onset laryngeal papillomatosis; HPV, human papillomavirus;

M, male; F, female; Epi, episomal; MT, malignant transformation; N, no; Y, yes;

ND, Not done; APOT, amplification of papillomavirus oncogene transcripts;

$\mathrm{R}$, right; L, left; B, both; TVC, true vocal cord; FVC, false vocal cord; AF, aryepiglottic fold

*The HPV-6 subtype could not be identified due to insufficient tissue.

The subtype of HPV-6 could not be identified for case 9 due to insufficient tissue. URR sequences and methylation patterns were further analyzed in 10 fresh-frozen specimens collected from 6 of the 11 patients with HPV6-positive AO-LP, including 6 initial lesions (derived from cases 1 and 3 to 7) and 4 recurrent lesions (cases 5-R1, 5-R2, 6-R1, and 7-R1). Among the $96 \mathrm{CpG}$ sites (16/case), $67(69.8 \%)$ were completely unmethylated, while $23(30.2 \%)$ were heterogeneous ( $\geq 1$ methylated CpG clone). The mean methylation rate in the 6 initial lesions was $5.2 \%$ (ranging from $1.0 \%$ to $8.3 \%$ ) for the entire URR region, $3.7 \%$ in the $5^{\prime}$-URR, $4.6 \%$ in the E6 enhancer, and $6.7 \%$ in the p97 promoter. All CpG clones were unmethylated at nt 7650 , which is a $\mathrm{CpG}$ site of E2BS1, and at nt 7798. At least one $\mathrm{CpG}$ clone was methylated at the other $\mathrm{CpG}$ sites. Specifically, heterogeneous methylation was found in $50 \%(3 / 6)$ of patients at nt 7953 and nt 7963 of E2BS2, and at nt 58 of E2BS4 within the p97 promoter (Figure 3).

\section{Expression of $\mathrm{p16}^{\mathrm{INK} 4 \mathrm{a}}, \mathrm{p53}$, and $\mathrm{pRb}$ in $\mathrm{AO}-\mathrm{LP}$}

The expression of cell cycle proteins ( $\mathrm{p} 16^{\mathrm{INK} 4 \mathrm{a}}$, $\mathrm{p} 53$, and $\mathrm{pRb}$ ) in 9 of 11 patients with HPV-positive or -negative AO-LP, including cases 1 to 9, was examined by immunohistochemistry (Figure 4). In the $7 \mathrm{HPV}$ positive patients, $\mathrm{pRb}$ expression was found in 3 cases (42.9\%), alongside low percentages of p16 ${ }^{\mathrm{INK} 4 \mathrm{a}}(28.6 \%$, $2 / 7)$ and p53 expression (14.3\%, 1/7; Table 1). None of the suppressor proteins $\left(\mathrm{p} 16^{\mathrm{INK} 4 \mathrm{a}}, \mathrm{p} 53\right.$, and $\left.\mathrm{pRb}\right)$ were expressed in the unique case that developed asynchronous laryngeal papillomatosis and carcinoma. 
A)

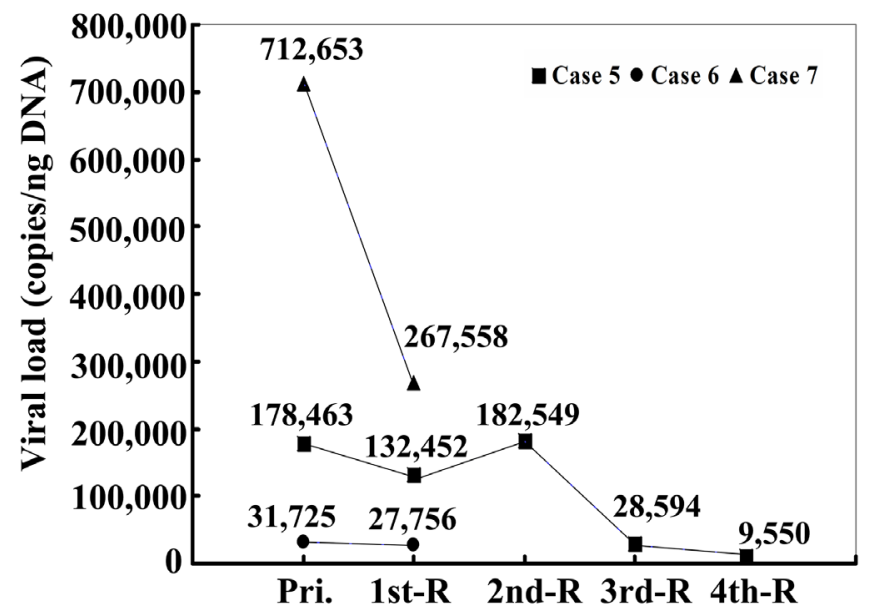

B)

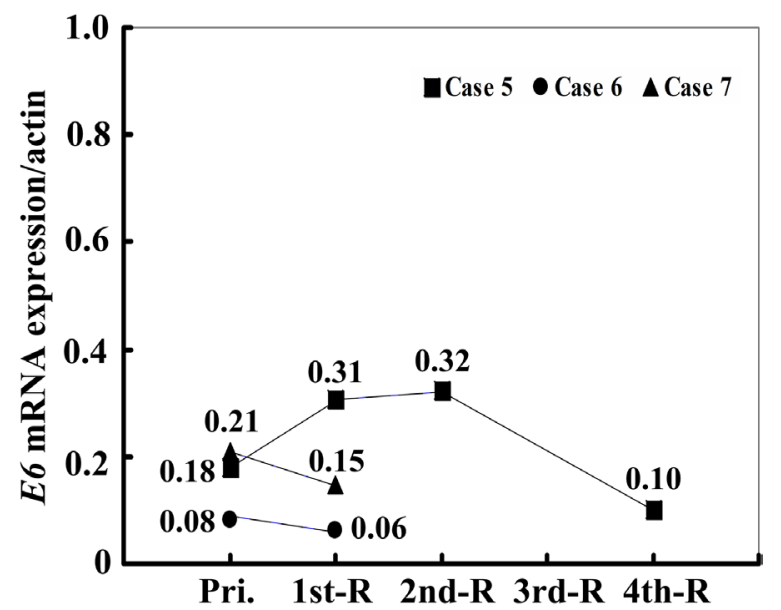

Figure 1: (A) Dynamic variation of viral load and (B) E6 mRNA expression of HPV-6 in AO-LP before the first treatment, and after recurrences. Compared with the primary lesion, a gradual decline in the tendency of HPV-6 copy numbers and mRNA expression in the recurrent lesions was found in cases 5,6, and 7 over time after surgical treatment. Pri.: primary tumor without treatment; 1 1st-R: first recurrence; 2nd-R: second recurrence; 3rd-R: third recurrence; 4th-R: fourth recurrence.

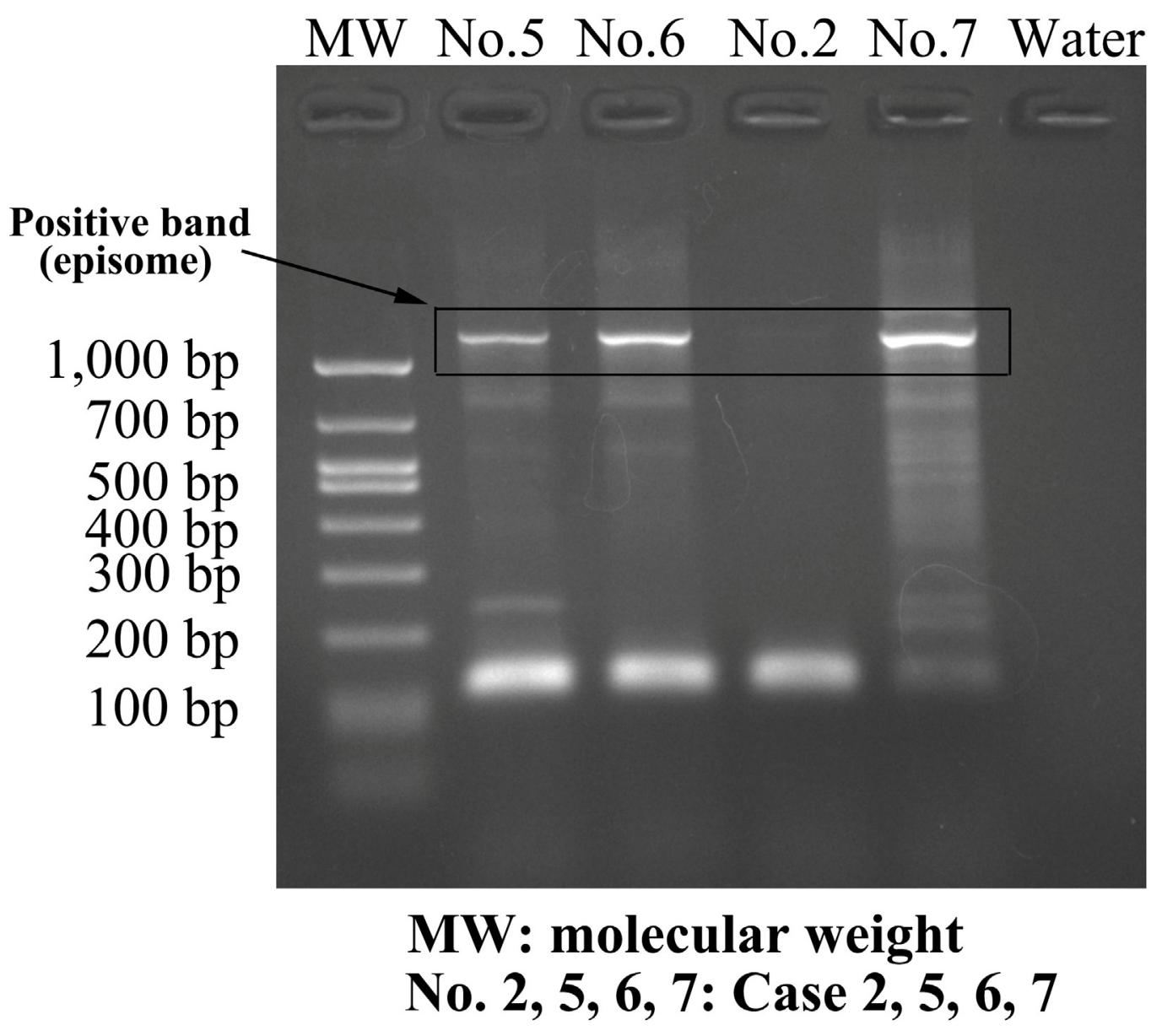

Figure 2: Amplification of papillomavirus oncogene transcripts (APOT) of HPV-6. In several typical cases with HPV-6positive status, including cases 5,6 , and 7 , amplimers of approximately $1200 \mathrm{bp}$ in length were suspected to originate from the E7-E1^E4 episomal transcript, and were confirmed by direct sequencing of amplification products. Case 2 was HPV negative. 


\section{DISCUSSION}

We studied only HPV-6 because this virus is a unique subtype found in AO-LP populations. The prevalence of HPV-6 (81.8\%) was consistent with previous studies, in which $75-80 \%$ of the papillomas harbored HPV-6 [22, 23]. Regarding LR-HPV-6 in AOLP, Forslund et al. measured the $E 2 / E 7$ ratio by real-time
PCR to determine the physical status of HPV-6 in 25 papilloma samples, and found that laryngeal papillomas and healthy tissue harbored only episomal HPV-6 [24]. A previous study demonstrated that E6 and E7 proteins in LR-HPV are necessary for stable episomal maintenance of LR-HPV genomes [25]. In the present study, we designed two new 5'-primers and developed APOT for HPV-6 based on the method described by Klaes et al. [20], and only
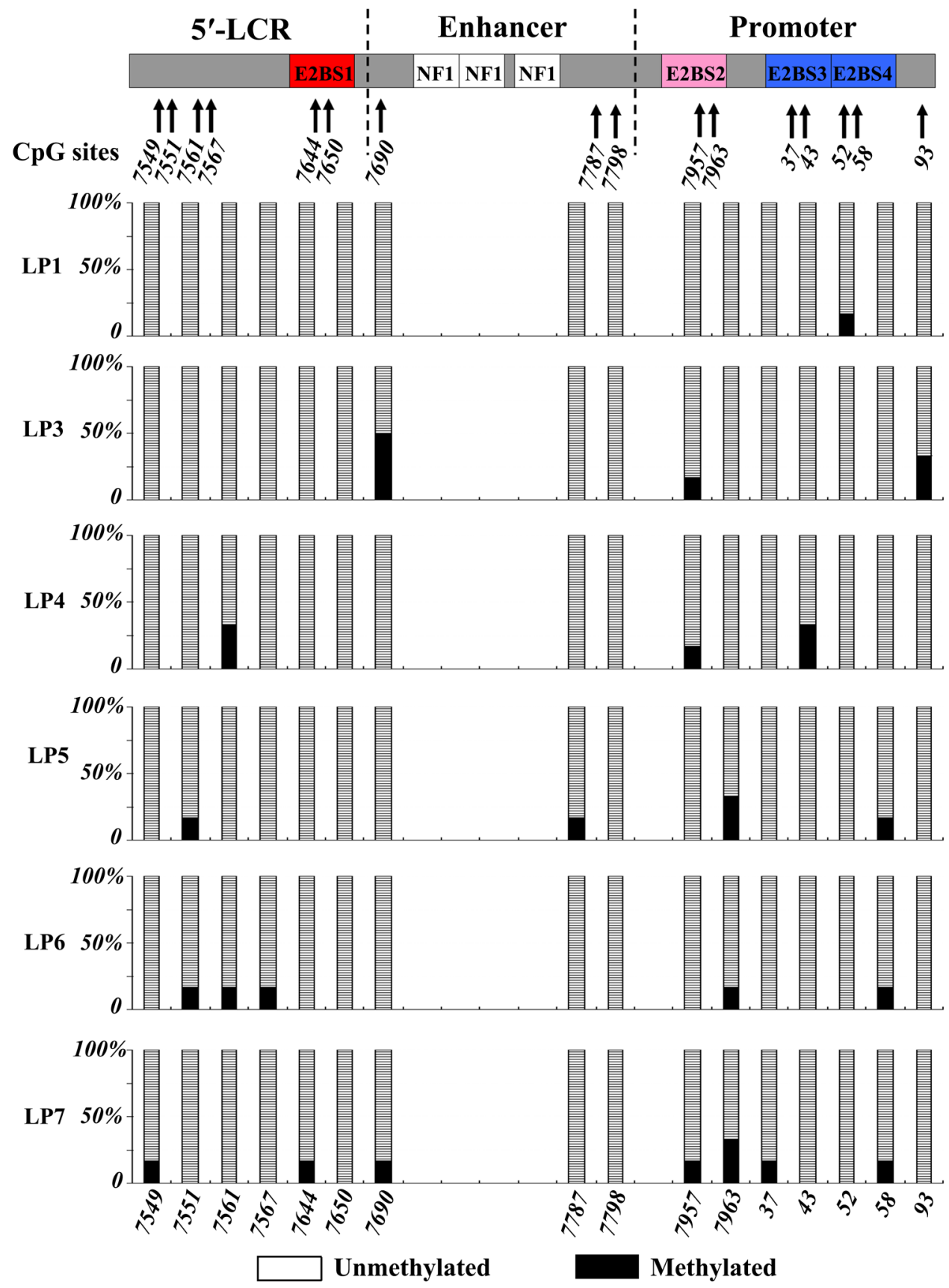

Figure 3: Methylation of CpGs sites at the URR of HPV-6 in AO-LP. For every CpG site, 6 clones were sequenced to identify the presence and frequency of meCpG clones. The left vertical bar indicates the percentages of meCpG clones. The structural diagrams of the URR and the positions of the $\mathrm{CpG}$ sites are shown at the top and bottom of the figure, respectively. The CpGs in the URR are numbered according to the amended version of HPV6b. 
the episomal status of virus was identified in all HPV-6positive AO-LP samples. The persistent expression of E6 mRNA may contribute to the maintenance of episomal status and replication of HPV-6 in AO-LP.

In a previous study, Huebbers et al. reported a female patient who underwent several hundred revision surgeries for juvenile-onset recurrent respiratory papillomatosis, and eventually developed laryngeal SCC. They identified only the episomal virus in the papilloma and HPV-6 integration in the carcinoma. Loss of the expression of AKR1C3 induced by viral integration may be related to malignant transformation of papillomatosis [26]. In the present study, the patient who developed laryngeal SCC after resection of the papilloma did not harbor HPV-6. Our findings did not support an association between LR-HPV types and the development of laryngeal squamous intraepithelial tumors, and suggest that a carcinogenic mechanism other than HPV-6-related malignant transformation from AO-LP to carcinoma was involved.

To our knowledge, this study is the first to demonstrate dynamic variations in HPV-6 viral loads and mRNA expression among patients with AO-LP. Although no relationship between viral load and recurrence could be established due to the limitation of sample size, our results showed a gradual decline in the tendency of HPV-6 copy numbers and mRNA expression over time after surgical treatment. Both the findings of Forslund et al. [24] and our findings consistently demonstrated large variations in HPV-6 copy numbers among laryngeal papilloma samples. In addition, Forslund et al. reported that the quantity of HPV-6 is not associated with the number of surgical procedures performed since the onset of disease, and they observed significantly higher HPV-6 loads in papillomas compared with paired healthy tissue [24]. Mikolajczak et al. showed that the HPV-6 viral load in AO-LP decreased gradually to zero following several surgeries and intralesional cidofovir therapy. They suggested that relapses can occur if latent laryngeal HPV reservoirs are not eradicated, and HPV replication might recommence from those sites after the end of therapy [22]. Therefore, these findings suggest that the resection range of the lesion should be based not only on pathological diagnosis but also on HPV-6 loads in the adjacent tissues. Persistent infection or residual HPV-6 after treatment may contribute to recurrences of AO-LP. Low-risk E6 and E7 proteins retain many of the same abilities as high-risk proteins that provide redundant mechanisms for promoting cellular proliferation, disrupting apoptosis, and uncoupling cellular differentiation [27]. However, E6 and E7 proteins of LRHPVs do not seem to express cell-transforming activities comparable with those of their high-risk counterparts [9]. It is known that the ability to promote the degradation of p53 is restricted to high-risk HPV types [8]. In addition, low-risk E7 binds to $\mathrm{pRb}$ family members with lower affinity than high-risk E7 [25] and does not target $\mathrm{pRb}$ for degradation [9]. Thus, although patients may experience multiple recurrences, tumors rarely undergo malignant transformation.

Previous studies have demonstrated that the methylation of high-risk HPV URR is an important feature in cervical neoplasms, and that it regulates the expression of E6 and $E 7$ oncogenes by adjusting the binding of viral E2 protein to the E2BSs $[12,17]$. Reuschenbach et al. [28] found that patients with high methylation
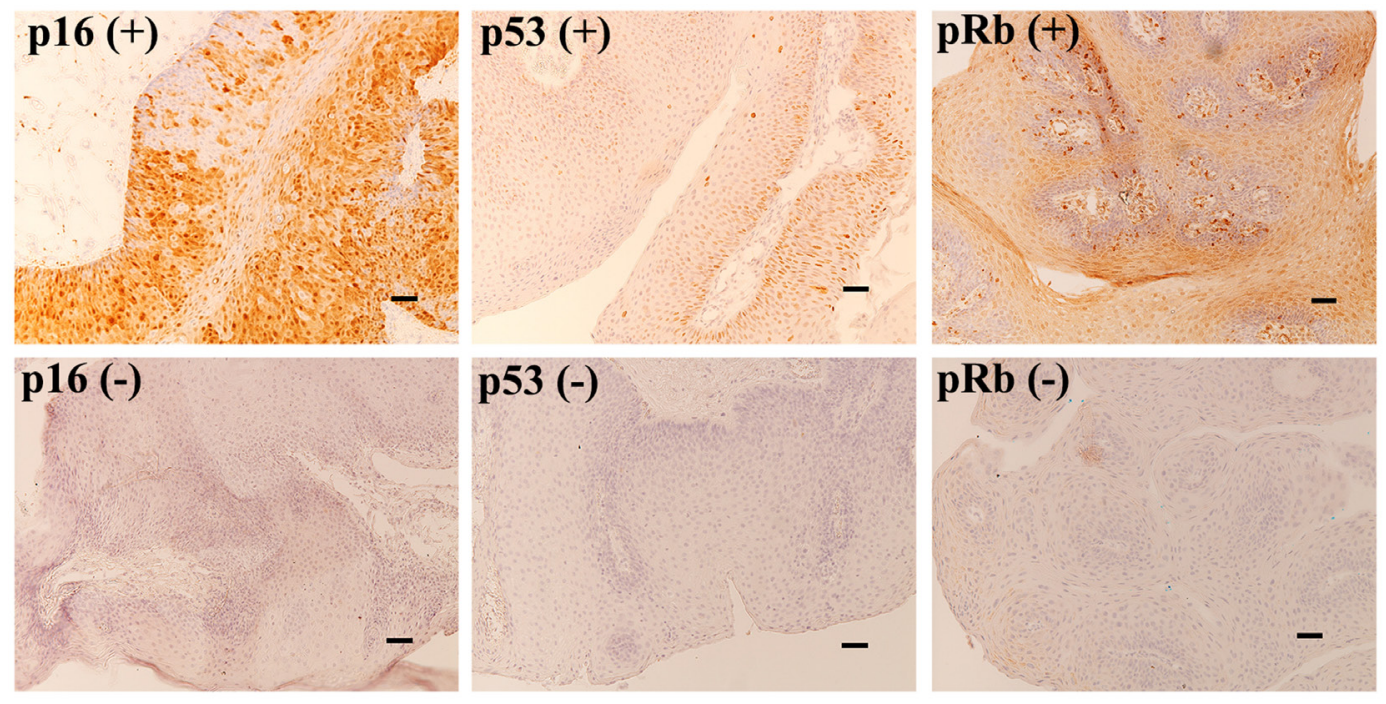

Figure 4: Immunohistochemistry for p16, p53, and pRb in AO-LP. Positive expression was defined as p16INK4a staining in $>40 \%$, or p53 and pRb staining in $>25 \%$ of 2000 tumor cells. The six micrographs show the typical p16, p53, and pRb immunoreactivity patterns corresponding to positive and negative expression $(\times 100$; bar, $100 \mu \mathrm{m})$. 
Table 2: Primers for real-time PCR, APOT and bisulfite-sequencing PCR for HPV-6

\begin{tabular}{|c|c|}
\hline Primers & Sequences $\left(5^{\prime}\right.$ to $\left.3^{\prime}\right)$ \\
\hline \multicolumn{2}{|l|}{ Real-time PCR } \\
\hline HPV6-RP-forward & GCGTGCTGCCTAGAATTTCAT \\
\hline HPV6-RP-reverse & CAACAGTTGTTGCATATCCAGCAT \\
\hline HPV6-probe & FAM-CAAAGTGTCTATATTGGTTAATTTTTC-NFQ \\
\hline \multicolumn{2}{|l|}{ APOT } \\
\hline HPV6-P1 & ACCCTGTAGGGTTACATTGC \\
\hline HPV6-P2 & ACAGCAACGTTCGACTGGTTGTGCAG \\
\hline HPV6-P3 & GACTCGAGTCGACATCG \\
\hline \multicolumn{2}{|c|}{ Bisulfite-sequencing PCR } \\
\hline Met_HPV6_URR 1F & TWRTTATATTTTGTGATTTAGTGGTTGTTGTA \\
\hline Met_HPV6_URR 1R & AACACATTATAACAAATTAATAMAAAАTATATACYAAAAАCA \\
\hline Met_HPV6_URR 2F & GGTTGTTTTTRGTATATATTTTKTATTAATTTGTTAT \\
\hline Met_HPV6_URR 2R & AATTAACTACAATACATAAAAATATAACAC \\
\hline Met_HPV6_URR 3F & GTTTGGTATATAATAATATAAAAATGAGTAATTTAAGGTTATAT \\
\hline Met_HPV6_URR 3R & TTACAACATATACATAAATAAATTAAACATCTTACACAAC \\
\hline
\end{tabular}

APOT: amplification of papillomavirus oncogene transcripts

levels at E2BS3 and E2BS4 had the highest E6 and E7 expression levels, and the methylation of E2BS3 and E2BS4 in oropharyngeal SCCs is associated with E2 integrity and viral physical status. However, there are few studies on the methylation of LR-HPVs in AO-LP. Ure and Forslund reported a lack of methylation in HPV6 URR from AO-RRP by analyzing 360 clones derived from both basal/intermediate and superficial cells of 6 HPV-6-positive samples. In their study, no methylated $\mathrm{CpG}$ was detected in any of the URRs investigated [18]. In the present study, although complete unmethylation was found in most $\mathrm{CpG}$ sites of HPV-6 URR, sporadic $\mathrm{CpG}$ sites were heterogeneously methylated, including nt 7953 and nt 7963 of E2BS2, and nt 58 of E2BS4. Nevertheless, no correlation between heterogeneous methylation of E2BSs and E6 expression levels in HPV6-positive AO-LP cases was found. Although the number of samples was limited, our findings provided further evidence of unmethylation in HPV-6 URR and suggested that the methylation of sporadic $\mathrm{CpG}$ sites within E2BSs does not sufficiently influence the expression of $E 6$ and E7 oncogenes in AO-LP. Moreover, the low frequency of p16 ${ }^{\mathrm{INK} 4 \mathrm{a}}$ overexpression and low expression of p53 in AOLP were independent of HPV-6 infection in this study. A previous study by Mooren et al. revealed highly variable staining patterns of $\mathrm{p} 16^{\mathrm{INK} 4 \mathrm{a}}$ in head and neck papillomas and laryngeal dysplasia, irrespective of HPV status [29]. We did not identify an association between recurrence and the expression of $\mathrm{p} 16^{\mathrm{INK} 4 \mathrm{~A}}, \mathrm{p} 53$, and $\mathrm{pRb}$. Further studies of large sample sizes should be conducted to investigate associations between the expression of cell-cycle proteins and recurrence.

In summary, high viral loads and episomal HPV-6 were frequently observed in AO-LP, and persistent E6/ E7 mRNA expression of LR-HPV-6 may be associated with the recurrence of papillomas. Hypomethylation and the scattered patterns of methylated CpGs at the URR of HPV-6 were identified in AO-LP, but our findings did not provide any evidence of malignant transformation from laryngeal papilloma to carcinoma induced by HPV-6. P1 ${ }^{\text {INK4a }}$ cannot be recommended as a surrogate biomarker for HPV infection in AO-LP.

\section{MATERIALS AND METHODS}

\section{Ethics statement}

The study was approved by the Ethics Committee of University of the Ryukyus, and all participants gave written informed consent. All procedures were conducted in accordance with the ethical standards of the Declaration of Helsinki (1975).

\section{Study population and specimens}

The study included 16 fresh-frozen tissues and 2 formalin-fixed paraffin-embedded (FFPE) specimens obtained from 11 patients with AO-LP who were diagnosed 
and treated in the Department of Otorhinolaryngology, Head and Neck Surgery, Graduate School of Medicine, University of the Ryukyus, between September 2009 and February 2017.

\section{Extraction of nucleic acids}

Tissue samples were snap-frozen in liquid nitrogen during biopsy or surgical excision and stored in liquid nitrogen for further analysis. A Gentra Purification Tissue Kit (Qiagen, Germantown, MD) was used to isolate DNA from the fresh-frozen samples. The extraction processes were conducted according to the manufacturer's specifications using the solutions provided in the kit. For the FFPE samples, DNA was extracted by the TaKaRa DEXPAT Easy (TaKaRa, Tokyo, Japan) following the manufacturer's instructions.

Total RNA was isolated from 5- to 10-mg frozen tumor samples using the ToTALLY RNA kit (Ambion, Austin, TX), according to the manufacturer's instructions, and suspended in $50 \mu \mathrm{L}$ ultra-high-quality diethyl pyrocarbonate-treated water. Before cDNA synthesis, any residual DNA was removed through incubation with 1 U DNase I (Ambion) at room temperature for $25 \mathrm{~min}$. cDNA was then synthesized from DNA-free total RNA using the RETROscript Kit (Ambion), according to the manufacturer's instructions. All assays were performed both with and without reverse transcriptase to examine the presence of contaminating DNA in RNA samples.

\section{PCR for detecting LR-HPV-6 DNA}

The presence of HPV-6 DNA was detected by PCR with two general consensus primer sets, GP5+/GP6+ and MY11/MY09, as described previously [19]. Positive PCR products were purified and directly sequenced, and the sequences obtained were aligned and compared to those of known HPV types in the GenBank database using the BLAST program.

\section{Viral load and mRNA expression detected by real-time PCR}

To detect the viral loads of HPV-6, a quantitative real-time PCR (qRT-PCR) was conducted with the ABI Prism 7300 Sequence Detection System (Applied Biosystems, Carlsbad, CA) and Taqman PCR Master Mix II (Roche Molecular Systems, Foster City, CA). We designed the primers and Taqman probes to target the HPV-6 E6 open reading frames (Table 2). The E6 probe was labeled with FAM at the $5^{\prime}$ end and with NFQ at the $3^{\prime}$ end (Applied Biosystems Japan, Tokyo, Japan). Amplification conditions were as follows: $2 \mathrm{~min}$ at $50{ }^{\circ} \mathrm{C}$, $10 \mathrm{~min}$ at $95^{\circ} \mathrm{C}$, and a two-step cycle of $95^{\circ} \mathrm{C}$ for $15 \mathrm{~s}$ and $60{ }^{\circ} \mathrm{C}$ for $60 \mathrm{~s}$ for a total of 50 cycles. A standard curve for the $E 6$ genes was generated by amplification of serial 10-fold dilutions $\left(10^{1}, 10^{2}, 10^{3}, 10^{4}, 10^{5}\right.$, and $10^{6}$ viral copies) of a plasmid p1478 carrying the HPV-6b E6 early region (Addgene, Cambridge, MA). Viral DNA load was determined by calculating E6 copy numbers. Cellular DNA quantification was determined by PCR amplification of $\beta$-globin, as described previously [19].

A qRT-PCR with the same E6 primers and probes and the same protocol as that described for the detection of viral load in the previous section was used to estimate cDNA viral load as a measurement of mRNA quantity in the samples, and the quantitative value of $E 6$ mRNA was described as each value relative to $\beta$-actin mRNA. The $\beta$-actin primers and probes were designed as reported previously [30].

\section{Detection of HPV-6 physical state by the amplification of papillomavirus oncogene transcripts assay}

The $3^{\prime}$ rapid amplification of cDNA ends (RACE) amplification of papillomavirus oncogene transcripts (APOT) assay described previously by Klaes et al. [20] was modified and performed to detect the physical status of HPV-6. We designed and combined a new set of 5'-primers (first 5'-primer, HPV-6-p1; second 5'-primer, HPV-6-p2) with a 3'-Frohman primer (for both nested PCR setups described in Klaes' study) for nested PCR (Table 2). PCR products of interest were excised from the gel after electrophoresis and extracted using the Wizard Purification Kit (Promega, Madison, WI) for direct sequencing. Sequencing results were analyzed using BLASTN-program provided by the National Cancer Institute (Bethesda, MD).

\section{HPV-6 methylation analysis}

DNA (1-2 $\mu \mathrm{g})$ extracted from tissue samples was converted with bisulfite using an EpiTect1 Plus Bisulfite Kit (QIAGEN, Valencia, CA), according to the manufacturer's protocol. The modified DNA was amplified in 3 amplicons with bisulfite-sequencing PCR (BSP) primer assays as BSP-1, BSP-2, and BSP-3 covering the 5 '-LCR, and enhancer and promoter regions of the HPV-6 URR, containing $16 \mathrm{CpGs}$ and E2BSs 1, 2, 3, and 4. The primer sequences are shown in Table 2 . The $25 \mu \mathrm{L}$ PCR mixture contained $0.2 \mathrm{mM}$ of each of the $4 \mathrm{dNTPs}, 2 \mathrm{mM}$ $\mathrm{MgCl}_{2}, 10 \mathrm{pmol}$ of each primer, 1.25 units AmpliTaq DNA Polymerase (Applied Biosystems) and 300 ng bisulfitemodified DNA. Amplification was carried out under the following conditions: $95{ }^{\circ} \mathrm{C}$ for $5 \mathrm{~min}$, followed by 45 cycles at $95^{\circ} \mathrm{C}$ for $1 \mathrm{~min}, 54^{\circ} \mathrm{C}$ for $1 \mathrm{~min}$ and $72^{\circ} \mathrm{C}$ for 2 min, with a final extension at $72{ }^{\circ} \mathrm{C}$ for $7 \mathrm{~min}$.

After checking in $2 \%$ agarose gel, amplified products were gel purified using a Wizard1 SV Gel and PCR Clean-Up System (Promega) and cloned into the pCR ${ }^{\text {TM} 4-T O P O 1 ~ v e c t o r ~(I n v i t r o g e n, ~ C a r l s b a d, ~ C A) ~ f o r ~}$ 
sequencing. For each amplicon, at least 6 individual clones were sequenced using an ABI PRISM 3130xl Genetic Analyzer (Applied Biosystems).

\section{Immunohistochemistry for $\mathrm{p}^{\mathrm{INK} 4 \mathrm{a}}, \mathrm{p53}$, and pRb proteins}

Serial 4- $\mu$ m-thick sections from FFPE samples were deparaffinized in xylene and hydrated in a graded series of alcohol. Epitope retrieval was performed by heating at 95 $99^{\circ} \mathrm{C}$ for $10 \mathrm{~min}$ in Tris/EDTA buffer (pH 9.0). Endogenous peroxidase activity was quenched by incubating the sections in $3 \%$ hydrogen peroxide and $15 \mathrm{mM}$ sodium azide for 5 $\mathrm{min}$. The sections were subsequently incubated overnight at $4{ }^{\circ} \mathrm{C}$ with primary monoclonal mouse anti-p $16^{\mathrm{INK} 4 \mathrm{a}}$ antibody (MTM Laboratories AG, Heidelberg, Germany) for $\mathrm{p} 16^{\mathrm{INK} 4 \mathrm{a}}$ staining, primary monoclonal mouse anti-p53 antibody (1:500; Progen Biotech GmbH, Heidelberg, Germany) for p53 staining, and primary monoclonal mouse anti-pRb antibody (1:2000; Life-Span BioSciences, Seattle, $\mathrm{WA})$ for $\mathrm{pRb}$ staining. After extensive washing in PBS, the slides were incubated for $30 \mathrm{~min}$ at room temperature with a horseradish peroxidase-conjugated goat anti-mouse secondary antibody (MTM Laboratories). Immunolabeling was visualized by incubation in 3-3'-diaminobenzidine and stained slides were counterstained with hematoxylin. Cases were considered $\mathrm{pRb}$-, p53- or $\mathrm{p} 16^{\mathrm{INK} 4 \mathrm{a}}$-positive if intense nuclear and/or cytoplasmic reactivity was present. Positive expression was defined as $\mathrm{pRb}$ and $\mathrm{p} 53$ staining in more than $25 \%$ [31], or $\mathrm{p} 16^{\mathrm{INK} 4 \mathrm{a}}$ staining in $40 \%$ of 2000 tumor cells [32].

\section{Author contributions}

Z.D. carried out the molecular and histological studies, contributed to the analysis and interpretation of data, drafted the article, and revised it critically for important intellectual content. M.S. contributed to the conception and design of the study and revised the article critically for important intellectual content. T.I. carried out the molecular studies and contributed to the analysis and interpretation of data. A.K., S.M., A.G., T.U., and H.M. recruited and treated participants, took samples from patients, and revised the article critically for important intellectual content. C.Z. and T.Z. contributed to the analysis and interpretation of data, helped make the figures, and revised the article critically for important intellectual content. All authors had access to the data and read, contributed, and gave final approval of the version to be published.

\section{CONFLICTS OF INTEREST}

The authors declare that there are no conflicts of interest.

\section{FUNDING}

This study was supported by the Japan Society for the Promotion of Science (KAKENHI 26462611 to Z.D.), the Natural Science Foundation of Guangdong Province, China 2014A030310411 to Z.D.), and a grant from the Science and Technology Development Center, Ministry of Education of China (20134433120021 to Z.D.).

\section{REFERENCES}

1. Tommasino M. The human papillomavirus family and its role in carcinogenesis. Semin Cancer Biol. 2014; 26:13-21.

2. Derkay CS, Darrow DH. Recurrent respiratory papillomatosis. Ann Otol Rhinol Laryngol. 2006; 115:1-11.

3. Katsenos S, Becker HD. Recurrent respiratory papillomatosis: a rare chronic disease, difficult to treat, with potential to lung cancer transformation: apropos of two cases and a brief literature review. Case Rep Oncol. 2011; 4:162-71.

4. Kashima H, Mounts P, Leventhal B, Hruban RH. Sites of predilection in recurrent respiratory papillomatosis. Ann Otol Rhinol Laryngol. 1993; 102:580-83.

5. Duggan MA, Lim M, Gill MJ, Inoue M. HPV DNA typing of adult-onset respiratory papillomatosis. Laryngoscope. 1990; 100:639-42.

6. Schraff S, Derkay CS, Burke B, Lawson L. American Society of Pediatric Otolaryngology members' experience with recurrent respiratory papillomatosis and the use of adjuvant therapy. Arch Otolaryngol Head Neck Surg. 2004; 130:1039-42.

7. Baumann JL, Cohen S, Evjen AN, Law JH, Vadivelu S, Attia A, Schindler JS, Chung CH, Wirth PS, Meijer CJ, Snijders PJ, Yarbrough WG, Slebos RJ. Human papillomavirus in early laryngeal carcinoma. Laryngoscope. 2009; 119:1531-37.

8. Klingelhutz AJ, Foster SA, McDougall JK. Telomerase activation by the $\mathrm{E} 6$ gene product of human papillomavirus type 16. Nature. 1996; 380:79-82.

9. Storey A, Osborn K, Crawford L. Co-transformation by human papillomavirus types 6 and 11. J Gen Virol. 1990; 71:165-71.

10. Fernandez AF, Rosales C, Lopez-Nieva P, Graña O, Ballestar E, Ropero S, Espada J, Melo SA, Lujambio A, Fraga MF, Pino I, Javierre B, Carmona FJ, et al. The dynamic DNA methylomes of double-stranded DNA viruses associated with human cancer. Genome Res. 2009; 19:438-51.

11. Kim K, Garner-Hamrick PA, Fisher C, Lee D, Lambert PF. Methylation patterns of papillomavirus DNA, its influence on E2 function, and implications in viral infection. J Virol. 2003; 77:12450-59.

12. Ding DC, Chiang MH, Lai HC, Hsiung CA, Hsieh CY, Chu TY. Methylation of the long control region of HPV16 is 
related to the severity of cervical neoplasia. Eur J Obstet Gynecol Reprod Biol. 2009; 147:215-20.

13. Sun C, Reimers LL, Burk RD. Methylation of HPV16 genome $\mathrm{CpG}$ sites is associated with cervix precancer and cancer. Gynecol Oncol. 2011; 121:59-63.

14. Park IS, Chang X, Loyo M, Wu G, Chuang A, Kim MS, Chae YK, Lyford-Pike S, Westra WH, Saunders JR, Sidransky D, Pai SI. Characterization of the methylation patterns in human papillomavirus type 16 viral DNA in head and neck cancers. Cancer Prev Res (Phila). 2011; 4:207-17.

15. Vinokurova S, von Knebel Doeberitz M. Differential methylation of the HPV 16 upstream regulatory region during epithelial differentiation and neoplastic transformation. PLoS One. 2011; 6:e24451.

16. Das Ghosh D, Bhattacharjee B, Sen S, Premi L, Mukhopadhyay I, Chowdhury RR, Roy S, Sengupta S. Some novel insights on HPV16 related cervical cancer pathogenesis based on analyses of LCR methylation, viral load, E7 and E2/E4 expressions. PLoS One. 2012; 7:e44678.

17. Chaiwongkot A, Vinokurova S, Pientong C, Ekalaksananan $\mathrm{T}$, Kongyingyoes B, Kleebkaow P, Chumworathayi B, Patarapadungkit N, Reuschenbach M, von Knebel Doeberitz M. Differential methylation of E2 binding sites in episomal and integrated HPV 16 genomes in preinvasive and invasive cervical lesions. Int J Cancer. 2013; 132:2087-94.

18. Ure AE, Forslund O. Lack of methylation in the upstream region of human papillomavirus type 6 from aerodigestive tract papillomas. J Virol. 2012; 86:13790-94.

19. Deng Z, Hasegawa M, Kiyuna A, Matayoshi S, Uehara T, Agena S, Yamashita Y, Ogawa K, Maeda H, Suzuki M. Viral load, physical status, and E6/E7 mRNA expression of human papillomavirus in head and neck squamous cell carcinoma. Head Neck. 2013; 35:800-08.

20. Klaes R, Woerner SM, Ridder R, Wentzensen N, Duerst M, Schneider A, Lotz B, Melsheimer P, von Knebel Doeberitz M. Detection of high-risk cervical intraepithelial neoplasia and cervical cancer by amplification of transcripts derived from integrated papillomavirus oncogenes. Cancer Res. 1999; 59:6132-36.

21. Combrinck CE, Seedat RY, Randall C, Roodt Y, Burt FJ. Novel HPV-6 variants of human papillomavirus causing recurrent respiratory papillomatosis in southern Africa. Epidemiol Infect. 2012; 140:1095-101.

22. Mikolajczak S, Quante G, Weissenborn S, Wafaisade A, Wieland U, Lüers JC, Klussmann JP, Beutner D. The impact of cidofovir treatment on viral loads in adult recurrent respiratory papillomatosis. Eur Arch Otorhinolaryngol. 2012; 269:2543-48.

23. Loizou C, Laurell G, Arvidsson A, Lindquist D, Nylander $\mathrm{K}$, Olofsson K. Recurrent respiratory papillomatosis in northern Sweden: clinical characteristics and practical guidance. Acta Otolaryngol. 2015; 135:1058-64.
24. Forslund O, Schwartz S, Olofsson K, Rydell R. Viral load and mRNA expression of HPV type 6 among cases with recurrent respiratory papillomatosis. Laryngoscope. 2016; 126:122-27.

25. Oh ST, Longworth MS, Laimins LA. Roles of the E6 and E7 proteins in the life cycle of low-risk human papillomavirus type 11. J Virol. 2004; 78:2620-26.

26. Huebbers CU, Preuss SF, Kolligs J, Vent J, Stenner M, Wieland U, Silling S, Drebber U, Speel EJ, Klussmann JP. Integration of HPV6 and downregulation of AKR1C3 expression mark malignant transformation in a patient with juvenile-onset laryngeal papillomatosis. PLoS One. 2013; 8:e57207.

27. Nominé Y, Masson M, Charbonnier S, Zanier K, Ristriani T, Deryckère F, Sibler AP, Desplancq D, Atkinson RA, Weiss E, Orfanoudakis G, Kieffer B, Travé G. Structural and functional analysis of E6 oncoprotein: insights in the molecular pathways of human papillomavirus-mediated pathogenesis. Mol Cell. 2006; 21:665-78.

28. Reuschenbach M, Huebbers CU, Prigge ES, Bermejo JL, Kalteis MS, Preuss SF, Seuthe IM, Kolligs J, Speel EJ, Olthof N, Kremer B, Wagner S, Klussmann JP, et al. Methylation status of HPV16 E2-binding sites classifies subtypes of HPV-associated oropharyngeal cancers. Cancer. 2015; 121:1966-76.

29. Mooren JJ, Gültekin SE, Straetmans JM, Haesevoets A, Peutz-Kootstra CJ, Huebbers CU, Dienes HP, Wieland U, Ramaekers FC, Kremer B, Speel EJ, Klussmann JP. P16(INK4A) immunostaining is a strong indicator for high-risk-HPV-associated oropharyngeal carcinomas and dysplasias, but is unreliable to predict low-risk-HPVinfection in head and neck papillomas and laryngeal dysplasias. Int J Cancer. 2014; 134:2108-17.

30. Deng Z, Hasegawa M, Yamashita Y, Matayoshi S, Kiyuna A, Agena S, Uehara T, Maeda H, Suzuki M. Prognostic value of human papillomavirus and squamous cell carcinoma antigen in head and neck squamous cell carcinoma. Cancer Sci. 2012; 103:2127-34.

31. Holzinger D, Flechtenmacher C, Henfling N, Kaden I, Grabe N, Lahrmann B, Schmitt M, Hess J, Pawlita M, Bosch FX. Identification of oropharyngeal squamous cell carcinomas with active HPV16 involvement by immunohistochemical analysis of the retinoblastoma protein pathway. Int J Cancer. 2013; 133:1389-99.

32. Deng Z, Hasegawa M, Aoki K, Matayoshi S, Kiyuna A, Yamashita Y, Uehara T, Agena S, Maeda H, Xie M, Suzuki M. A comprehensive evaluation of human papillomavirus positive status and p16INK4a overexpression as a prognostic biomarker in head and neck squamous cell carcinoma. Int J Oncol. 2014; 45:67-76. 